\title{
A NOTE ON THE SECONDARY SEXUAL CHARACTERS OF OMIOPHRON.
}

\author{
BY ROLAND HAYWARD, BOSTON, MASS.
}

While recently engaged in studying some specimens of Omophron americanum, my attention was attracted to the fact that in the males of this species the second joint of the middle tarsi is very distinctly dilated. The fact being new to me I was led to examine our other species in order to ascertain whether or not the character was common to all those occurring within our faunal limits. As a result I find that the North American species may be divided into two groups based upon this character. In the first the second joint of the middle tarsi is dilated; in the second it is simple as in the female. To the first may be referred the majority of our species, i, e.: labiatum, nitidum, obliteratum, dentatum, anerieamum, tessetlatum, and ozrale, while but two of those that I have been able to study, i. e.: gike and robustum, are referable to the second, Casey's species, concinnum, solilum, and gemma are unknown to me in nature.

The extent of dilation varies somewhat in the different species, being most marked in nitidum and apparently feeblest in tessellatum.

I have searched the books in rain for any mention of this character. All agree in stating that the first two joints of the anterior tarsi are dilated in the males, but I can find no reference to the middle tarsi of that sex differing from those of the female. It is not uncommon for this character to occur in certain gromps of the subfamily Harpaline, but I am not aware of its existence elsewhere in the Carabince.

\section{A PRELIMINARY SKETCH OF THE SPHINGICAMIPIDAE, A NEW GROUP OF PROTOSPHINGENE LEPIDOPTERA, WITH ITS SUBDIVISIONS. - I.}

\author{
BY A. S. PACKARD, PROVIDENCE, R. I.
}

After prolonged studies on a number of genera heretofore associated with the Saturniidae, I have cone to the conclusion, as indicated in P'srche, Dec., igor, p. 279, that they should be re- moved from that family and placed in a new family, or superfamily, group, which we may designate Sphingicampilat, from the most ancestral and typical genus, Sphingicampa. I should prefer to give 
the name of Protosphingina to the group, for recent prolonged examination of the larval, pupal and adult characters enable me to confirm the idea suggested by sereral others besides myself, that the Sphingiclae have almost directly descended from the Citheroninae (Ceratocampidae). The group also appears to have given origin to the Hemileucidae.

The Sphingicampidae may be thus brietly defined: Body often Splinx-like; antennae usually bipectinate, the tip more or less filiform; maxillae usually present, but small and weak; in some genera(Anisota, etc.) absent. The wings either small, narrow, Sphinx-like, or broad, large and saturniid in shape. Eleven veins in the fore wings, and in the hind wings eight (nine, invariably, in the Citheroniina). Discal cell usually small, invariably closed by the discal veins. The last subcostal vein, or vein $I I I_{2}$, often so detached as to form an "independent" vein.

Larva with stout spines (instead of the soft spiniferous tubercles of Saturniidae); larva sometimes smooth-bodied in the last stage, the median spine on 8 th abdominal segment always double. Anal legs very large; the typical and ancestral forms strikingly sphinx-like. Pupa with a large spine-like cremaster; subterranean, or situated under leares on the surface, a few species spiuning a slight thin cocoon, as occurs in some cases in the Sphingidae.

The group is, in accordance with our present knowledge, divided into six subdivisions which are either families or subfamilies or categories approximately. of that rank. We will for the present call them subfamilies.

These groups of Protosphingina may provisionally be thus defined.

I. Citheroniunat, with the characters of the group formerly named Ceratocampidae. Fore wings with eleven veins, hind wings with nine veins. The typical larval forms with long large thoracic and abdominal spines and the suranal plate tuberculated. Pupa subterranean, with a large cremaster. Sphingicampa, Syssphinx, Anisota, Eacles, Citheronia.

2. Aglimat. Head tending to be unusually narrow between the eyes; antennae bipectinated. Palpi large, 3-jointed; maxillae unusually well developed (in Aglia absent). Wings moderate, or very large, sometimes tailed. Vein $\mathrm{III}_{2}$ more or less detached and forming an independent rein. Discal cell very small. Larva in its last stage spineless, smooth; in the early stages with 2-6 thoracic spines, and a median double spine on Sth abdominal segment. Pupa like that of Eacles. Arsenura, Rhescyntis, Dysdaemonia, Bathyphlebia, Aglia, Polythysana, Cercophana, Eudelia.

3. L'rotinae. Antennae of $\delta$ with but a single pair of pectinations to a joint vein $\mathrm{III}_{2}$ independent; hind wings tailed. Larva in the last stage smooth, without spines. Trota.

This is a provisional group. Eudelia closely approaches Cercophana and the two approach Aglia on the one hand and Urota on the other. The venation of the fore wings is much as in Aglia, and 
the genera may have to be merged in with the Agliinae.

4. Bunacinae. Antennae bipectinate, tip filiform, or pectinated to the tip. Vein $\mathrm{III}_{2}$ is never detached so as to form an independent vein. Wings usually very large, and in the more specialized genera closely approaching the Saturnian Antheraea (a case of parallelism or convergence), but the larvae are entirely different, not spinning a dense cocoon and being armed with stout long spines (in certain genera spinulated), instead of soft tubercles crowned with several small short spines. Pupa like that of Eacles in type, ending in a large spine-like cremaster, and subterranean. Usta, Cirina, Imbrasia, Thyella, Bunaea, Antherina, Nudaurelia, Gynanisa, Lobobunaea, Salassa.

5. Cyrtogoniunae. Antennae of $\delta$ with a single pair of pectinations to a joint, in venation differing from that of the other groups, in veins $I I_{1}, I_{2}$ and $I_{4}$ of the fore wings all originating at nearly the same point, quite far beyond the outer end of the discal cell. This is an entirely provisional group (perhaps an offshoot from the Bunaeinae) as my material is imperfect, and we know nothing of the transformations of the single genus Cyrtogone.

6. Endaemoniinae. An aberrant group not improbably of full family rank, perhaps belonging here, or near Urotinae. The single genus is remarkable for the excessively long tails of the hind wings, the long slender palpi, the end of the second joint extending just beyond the front, and the third joint very long; and the venation. Head in front squarish; when denuded of scales flat, scarcely narrowing in front. Antennae of $\delta$ with but a single pair of pectinations to each joint. Maxillae very slender, not united, but nearly half as long as the palpi. Fore wings short and broad. Hind wings small, triangular, the tail being from three $(\$)$ to five times ( $\delta$ ) longer than the main portion of the wing. Ven. ation approaching that of Urota; Io veins in the fore wings, only 7 in the hind ones. The venation of the wings of the hinder pair is evidently affected by the great development of the "tail," which is strengthened by the three veins ( $\mathrm{III}_{3}$, $\left.I V_{1}, I V_{2}\right)$, no vein $V$ (internal) detected. The discal veins ("discocellulars") very unlike that of Urota or any other genus, and together forming a very oblique, bent or angulated line. The body is slender; the legs long and slender; the fore-tibial epiphysis rather long and about two-thirds as long as the tibia itself; the abdomen slender, that of the o clothed at the end with a large singular mop-like moss of dense, short battledoor-like scales, with a lateral tuft on each side.

The of genitalia show some remarkable features which we have not met with in this or allied families. While the claspers are in the main like those of Sphingicampa, etc., the suranal plate differs in shape and armature, being small and short, with a basal pair of small spines, and a second much longer pair directed backward and arising from the 
middle division of the plate. The penis is curved downward, armed with two sharp teeth, hollow beneath; below it arise two sharp slender accessory spines.

The beautiful brown or delicate pink tints, and the unusual multiplicity of ringlike discal and peridiscal spots, add to the bizarre nature of this form.

Larva spiny. "The larvae feed gregariously and are of a brownish green with black spines. The eggs are laid on the young green stems at the top of the tree (Dialium grumcense), and the pupae are found under the food-tree, lying on the surface beneath leaves." *.

Beutenmüller describes the larva as being armed with black spines a long the back and sides on " I, 2, 3, II and $\mathrm{I}_{2}$ segments." Remaining rows of spines yellow (green) tipped with black, with the spinules also tipped with black." (Journ. N. Y. Ent. Soc., v. p. 166, I897).

From his description we judge that the larsa is armed with spinulated spines, hence it does not belong with the Urotinae, the larra of Urota being smoothbodied in its final stage. It appears to be nearer to the Bunatimat, whose larvae in some cases have spinulated spines, and perhaps the group has arisen from that phylum.

\section{TWO NEW SPECIES OF OPHION.}

DY E. P. FELT, ALBANY, N. Y.

The members of this genus are extremely difficult to characterize in an entirely satisfactory manner and the descriptions of these two forms have remained unpublished for several years on this account.

Ophion (Eniscofilus) arcuatum sp. nov.Light fulvo-ferruginous, the larger opaque chitinous spot of the cubito-discoidal cell with a distinct arcuate continuation extending along the hinder margin of the glabrous area and partly around the smaller chitinous spot.

llead medium, yellowish posteriorly, face vellowish, antenrae slightly longer than the

"From a letter from Mr. A. J. Clements, Sierra I.eone, Africa, to Mr. William Schaus, published by W. Beutenmiiller in Journ. N. Y. Entomological Society, ix., p, 194, rgor. body ; ocelli black, equidistant; mandibles bidentate, fuscus apically. Thorax, sericeous; meso-thorax, convex; scutellum and postscutellum, prominent, the former yellowish; meta-thorax, slightly depressed in fiont of the transverse carina; lateral carinae distinct. Wings hyalite, having hardly a trace of the fuscus risible in Ophion (Euscopilus) furga. tum Say; marginal nerrure slightly thickened and sinuate near the small stigma; cubitodiscoidal nervure, weakly sinuate, not appendiculate; its bulla $\frac{1}{2}$ the width of the third discoidal cell trom its apex; two sub-triangular opaque spots in the glabrous atea of the cubito-discoirlal cell, the larger one with a chitinous, usually yellowish continuation along the hinder margin of the glabrous area to a point beyond the smaller chitinous spot, which latter is anturior and lateral of the center of the glabrous area. Legs, honey 

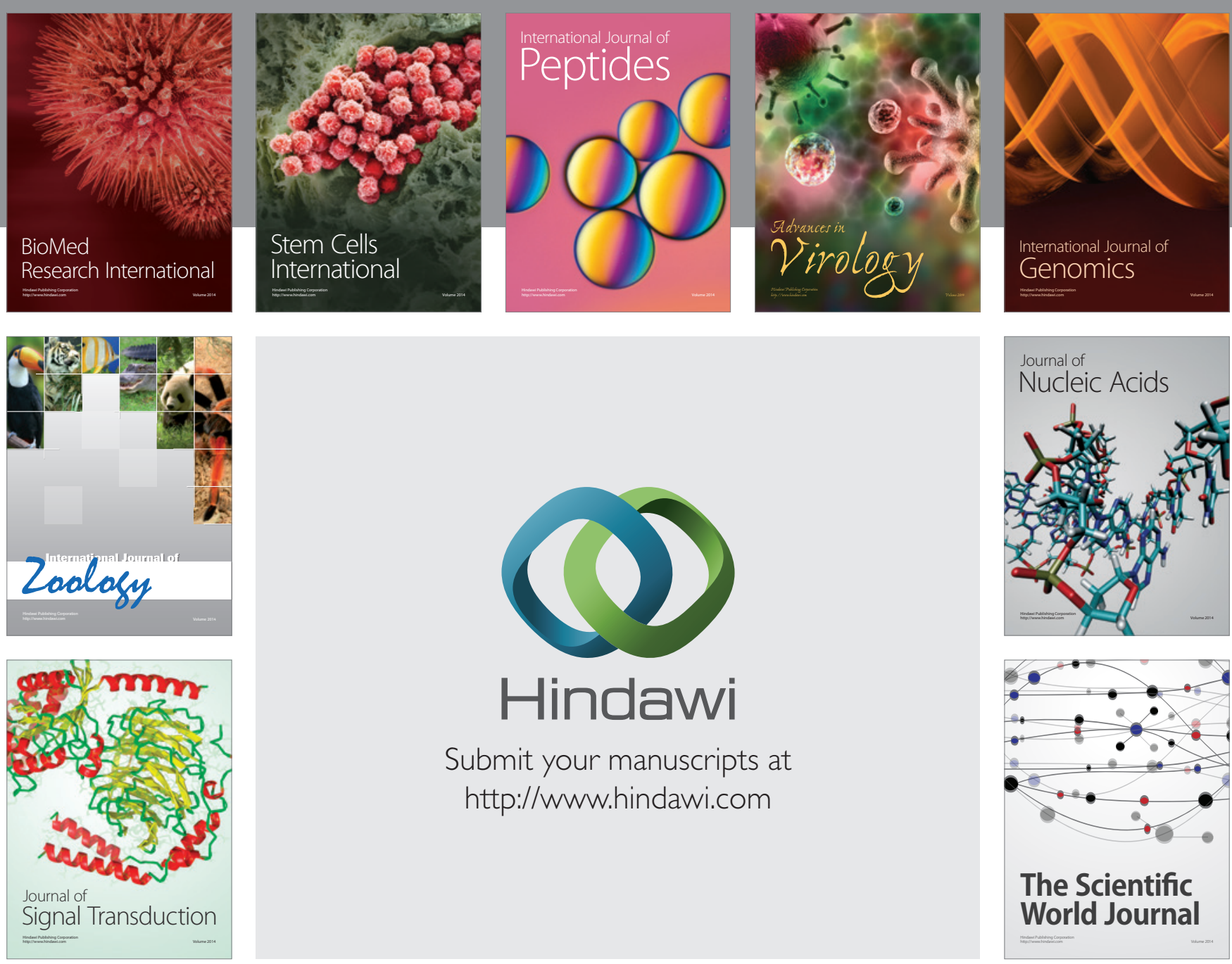

Submit your manuscripts at

http://www.hindawi.com
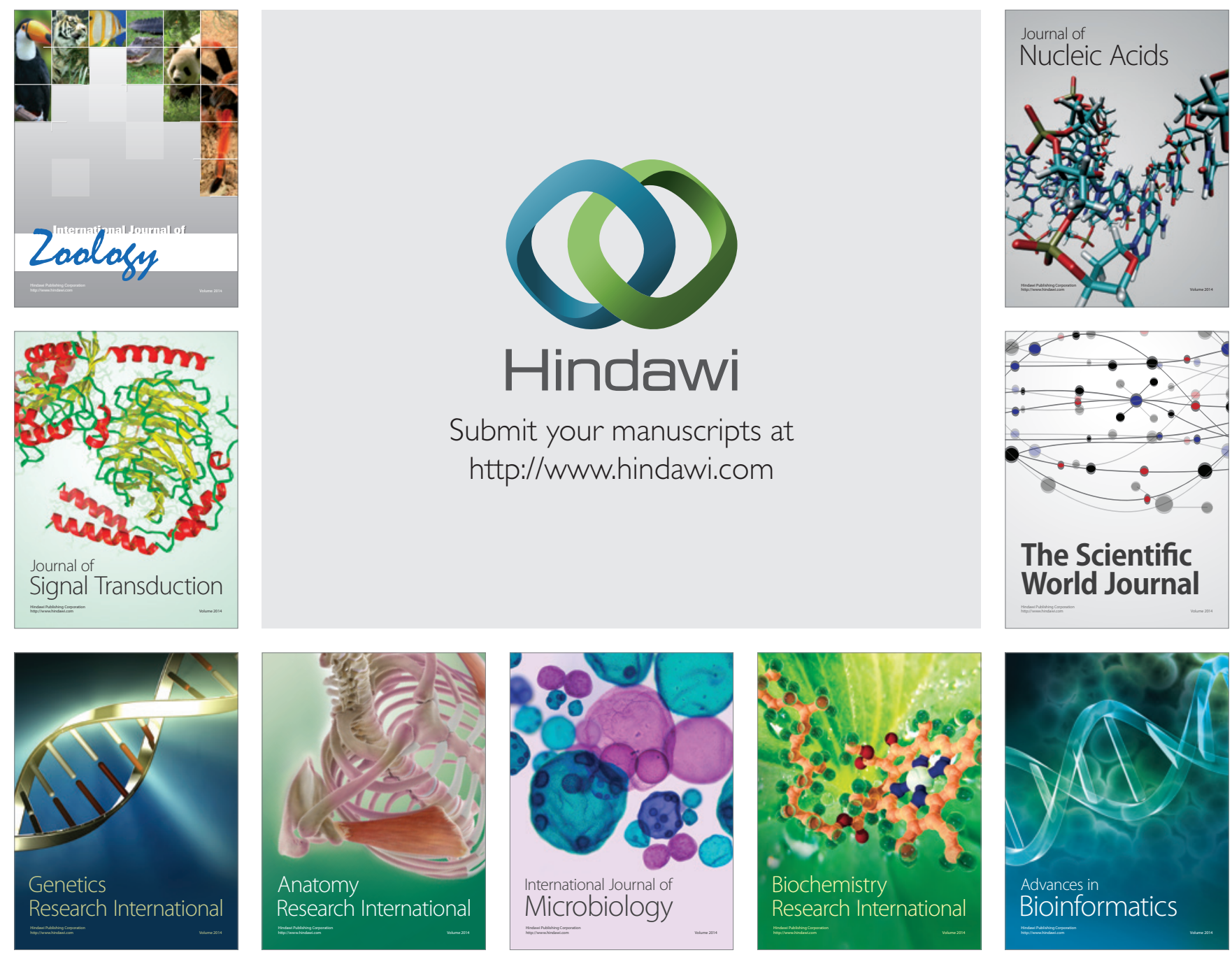

The Scientific World Journal
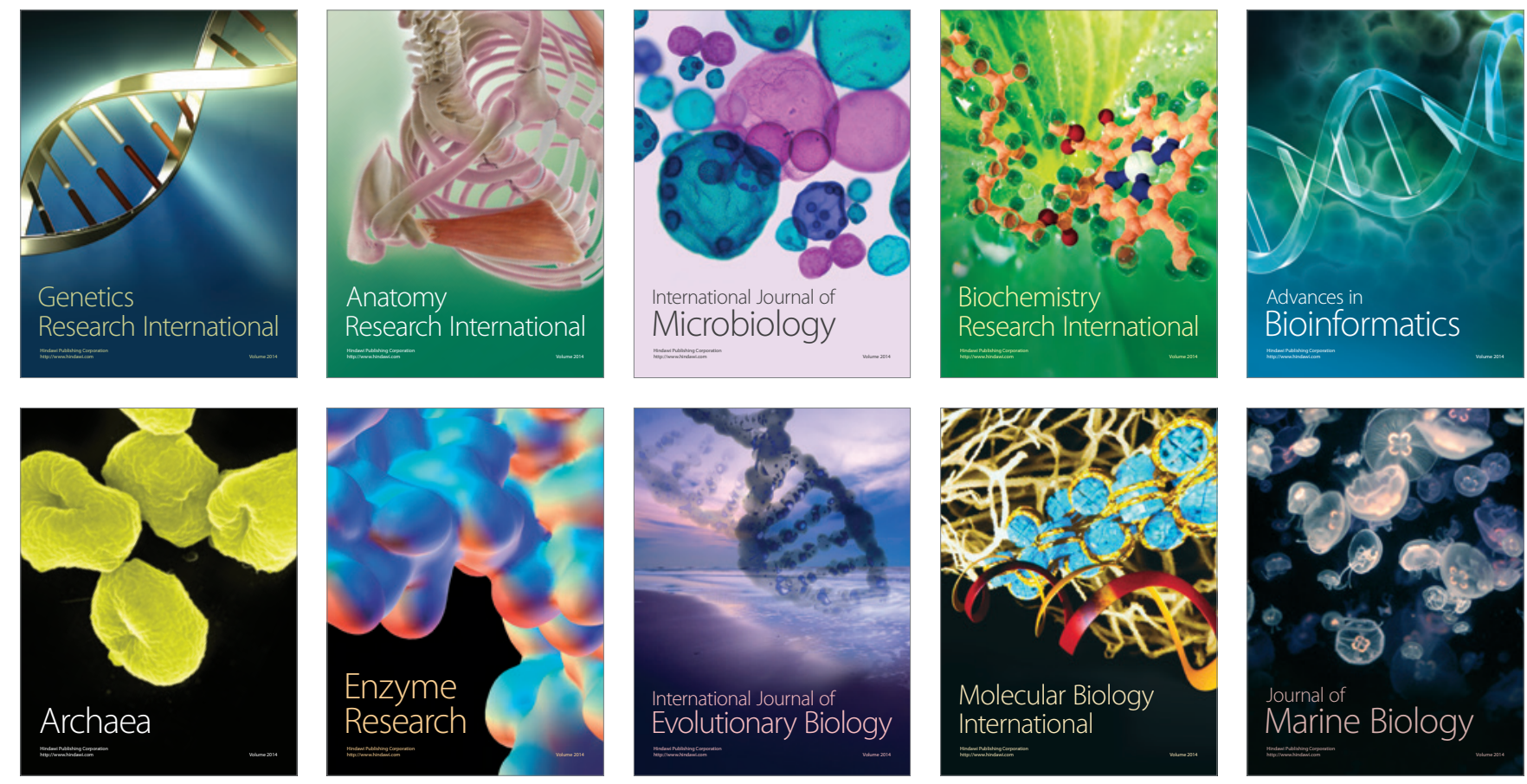